\title{
Effects of fumaric acid supplementation on methane production and rumen fermentation in goats fed diets varying in forage and concentrate particle size
}

\author{
Zongjun $\mathrm{Li}^{1+}$, Nannan Liu${ }^{1+}$, Yangchun Cao ${ }^{1}$, Chunjia Jin ${ }^{1}$, Fei $\mathrm{Li}^{1,2}$, Chuanjiang Cai ${ }^{1}$ and Junhu Yao ${ }^{1 *}$
}

\begin{abstract}
Background: In rumen fermentation, fumaric acid (FA) could competitively utilize hydrogen with methanogenesis to enhance propionate production and suppress methane emission, but both effects were diet-dependent. This study aimed to explore the effects of FA supplementation on methanogenesis and rumen fermentation in goats fed diets varying in forage and concentrate particle size.

Methods: Four rumen-cannulated goats were used in a $4 \times 4$ Latin square design with a $2 \times 2$ factorial arrangement of treatments: low or high ratio of forage particle size: concentrate particle size (Fps:Cps), without or with FA supplementation $(24 \mathrm{~g} / \mathrm{d})$. Fps:Cps was higher in the diet with chopped alfalfa hay plus ground corn than in that with ground alfalfa hay plus crushed corn.

Results: Both increasing dietary Fps:Cps and FA supplementation shifted ruminal volatile fatty acid (VFA) patterns toward more propionate and less acetate in goats. An interaction between dietary Fps:Cps and FA supplementation was observed for the ratio of acetate to propionate (A:P), which was more predominant when FA was supplemented in the low-Fps:Cps diet. Methane production was reduced by FA, and the reduction was larger in the low-Fps:Cps diet (31.72\%) than in the high-Fps:Cps diet (17.91\%). Fumaric acid decreased ruminal total VFA concentration and increased ruminal $\mathrm{pH}$. No difference was found in ruminal DM degradation of concentrate or alfalfa hay by dietary Fps:Cps or FA. Goats presented a lower ruminal methanogen abundance with FA supplementation and a higher B. fibrisolvens abundance with high dietary Fps:Cps.

Conclusions: Adjusting dietary Fps:Cps is an alternative dietary model for studying diet-dependent effects without changing dietary chemical composition. Fumaric acid supplementation in the low-Fps:Cps diet showed greater responses in methane mitigation and propionate increase.
\end{abstract}

Keywords: Feed particle size, Fumaric acid, Goat, Methane, Ruminal fermentation

\section{Background}

In ruminants, between $2 \%$ and $12 \%$ of feed energy is lost in the form of methane $\left(\mathrm{CH}_{4}\right)$ [1], which also contributes to global greenhouse gas emissions [2]. Increasing ruminal propionate production can not only decrease hydrogen available for methanogenesis but also increase the

\footnotetext{
* Correspondence: yaojunhu2004@sohu.com

${ }^{\dagger}$ Equal contributors

${ }^{1}$ College of Animal Science and Technology, Northwest A\&F University,

Yangling, Shaanxi 712100, China

Full list of author information is available at the end of the article
}

precursor available for gluconeogenesis in animals, improving feed efficiency $[3,4]$. Therefore, the metabolic intermediates of the propionate-succinate pathway, such as malic acid and fumaric acid (FA), have received widespread attention in relation to their contribution to ruminal propionate production [5-7]. However, in many trials, no contribution to ruminal propionate production was observed $[8,9]$. The conflicting results concerning responses to FA are probably attributable to dietdependent effects: Yang et al. [5] and García-Martínez et al. [10] found that FA supplementation showed greater 
responses in high-forage diets than in low-forage diets. Nevertheless, the diet-related mechanism of FA is elusive due to differences among experiments in nutrient intakes or ruminal fermentation characteristics, especially dissolved hydrogen concentrations and microbiota, which could affect the conversion of FA to propionate $[5,11]$.

As illustrated by Janssen [12], dissolved hydrogen concentration in the rumen was higher in animals fed readily digestible feed. Adjusting the particle size of dietary forage and concentrate can influence their ruminal degradation kinetics due to changing surface area available for rumen microbes and enzymes [13-16], and subsequent alterations in rumen fermentation characteristics [15-18]; therefore, this way allows dietary effects to be investigated without changing chemical composition. Considering that balancing diets for physically effective NDF (peNDF) and rumen degradable starch (RDS) is a key to maintaining proper ruminal $\mathrm{pH}$ [19-21] and that improper ruminal $\mathrm{pH}$ can suppress ruminal degradation kinetics [20-22], a long particle size of alfalfa hay was used in a diet with a small particle size of corn in this study. Furthermore, the responses in $\mathrm{CH}_{4}$ emissions to dietary particle size remain unclear [23]. In addition, to minimize the confounding factors of animals' feed intake and living environments, the experimental animals were limit-fed and kept in environmentally controlled chambers. The objective of this study was to investigate the effects of FA supplementation on $\mathrm{CH}_{4}$ production, ruminal fermentation, bacterial flora, and in situ feed degradation in goats that were fed diets that varied in forage and concentrate particle size.

\section{Methods}

\section{Animals, diets, and experimental design}

Experimental protocol was approved by the Animal Care and Use Committee of Northwest A\&F University (Yangling, China). Four non-lactating Xinong Saanen dairy goats with an initial live weight of $50 \pm 2.7 \mathrm{~kg}$, approximately $4 \mathrm{yr}$ of age, and with a permanent ruminal cannula were used. The goats were fed a ration that was formulated to meet the nutrient requirements for maintenance [24]. A total mixed ration (TMR) equivalent to $253 \mathrm{~g}$ alfalfa hay, $289 \mathrm{~g}$ corn silage, and $558 \mathrm{~g}$ concentrate (DM basis, Table 2) was offered to each goat twice daily in equal portions at 08:00 and 18:00 h. The goats had free access to drinking water. The amount of feed refused, if any, was recorded daily.

The goats were first allowed to adapt to the environmental chambers and the same TMR with chopped alfalfa hay and crushed corn over $4 \mathrm{wk}$, and then were assigned to a $4 \times 4$ Latin square design with a $2 \times 2$ factorial arrangement of treatments. The two factors were ratio of forage particle size to concentrate particle size
(Fps:Cps, high or low) and FA supplementation (0 or $24 \mathrm{~g} / \mathrm{d}$ ). The dietary Fps:Cps was modulated by varying the methods used to process alfalfa hay (chopped or ground) and corn (crushed or ground). As shown in Tables 1 and 2, Fps:Cps was higher in the diet with chopped alfalfa hay (78\% of particles $>8 \mathrm{~mm}$ ) and ground corn $(71 \%$ of particles $<1.18 \mathrm{~mm})$ than in the diet with ground alfalfa hay ( $75 \%$ of particles $<8 \mathrm{~mm}$ ) and crushed corn ( $74 \%$ of particles $>1.18 \mathrm{~mm}$ ). FA (Aladdin Industrial Corporation Co., Ltd., Shanghai, China) was offered twice daily in equal with diet. The current study consisted of four experimental periods, and each period consisted of $15 \mathrm{~d}$ of adaptation to treatments and $11 \mathrm{~d}$ of sampling. A 7-d washout period between experimental periods was used to minimize potential carryover effects between experimental diets. During the washout period, goats were fed the same TMR with chopped alfalfa hay and crushed corn.

Five indoor environmentally controlled chambers (each $7.4 \mathrm{~m} \times 4.2 \mathrm{~m} \times 2.7 \mathrm{~m}$ ) were used in this study, with one chamber serving as an adaptation chamber and four chambers as gas measurement chambers. The four goats were housed in the adaptation chamber and separated by placing each in a metabolic cage $(1.5 \mathrm{~m} \times$ $1.0 \mathrm{~m} \times 1.5 \mathrm{~m}$ ), and they were moved to the gas measurement chambers with their cages only during the days when gas emissions were measured. The temperature inside the chambers was maintained between 22 and $26{ }^{\circ} \mathrm{C}$, and the goats were subjected to a diurnal cycle of $14 \mathrm{~h}$ light and $10 \mathrm{~h}$ darkness throughout the experiment.

\section{Measuring daily methane production}

The construction, operation and animal welfare of environmentally controlled chambers have been described in detail by Li et al. [25]. Briefly, the 24-h gas emissions from each goat were measured in 2 consecutive days (d $16 \& 17, \mathrm{~d} 18$ \& 19) over 3 separate periods: 00:00 to $08: 00 \mathrm{~h}$ and $18: 00$ to $24: 00 \mathrm{~h}$ on the first day and then 08:00 to 18:00 $\mathrm{h}$ on the second day. At the end of each period, the chamber doors were kept open to allow fresh air in, and the chamber was cleaned before the next period. During the gas measurement periods, the air inside each chamber was mixed for $30 \mathrm{~s}$ every 10 min by 4 draft fans, and continuously and constantly

Table 1 The particle size distributions of alfalfa hay and corn using different processing method, \% DM retained on sieve

\begin{tabular}{lllllll}
\hline $\begin{array}{l}\text { Sieve } \\
\text { size }\end{array}$ & Alfalfa hay & & \multirow{2}{*}{$\begin{array}{l}\text { Sieve } \\
\text { size }\end{array}$} & & \multicolumn{2}{l}{ Corn } \\
\cline { 2 - 3 } & Chopped & Ground & & Crushed & Ground \\
\hline $19.0 \mathrm{~mm}$ & 31.8 & 0.7 & & $2.36 \mathrm{~mm}$ & 41.7 & 0 \\
$8.0 \mathrm{~mm}$ & 46.5 & 24.3 & & $1.18 \mathrm{~mm}$ & 32.0 & 29.5 \\
$1.18 \mathrm{~mm}$ & 13.2 & 45.2 & & $0.55 \mathrm{~mm}$ & 14.5 & 33.6 \\
Pan & 8.5 & 29.8 & Pan & 11.8 & 36.9 \\
\hline
\end{tabular}


Table 2 Ingredients and chemical composition of experimental diets

\begin{tabular}{|c|c|c|}
\hline \multirow[t]{2}{*}{ Items } & \multicolumn{2}{|c|}{ Treatment diet } \\
\hline & Low-Fps:Cps & High-Fps:Cps \\
\hline \multicolumn{3}{|l|}{ Ingredients, g/kg DM } \\
\hline Crushed corn & 370 & - \\
\hline Ground corn & - & 370 \\
\hline Chopped alfalfa hay & - & 230 \\
\hline Ground alfalfa hay & 230 & - \\
\hline Corn silage & 263 & 263 \\
\hline Cottonseed meal & 40 & 40 \\
\hline Soybean meal & 85 & 85 \\
\hline Premix ${ }^{a}$ & 5 & 5 \\
\hline $\mathrm{CaHPO}_{4}$ & 2.5 & 2.5 \\
\hline Salt & 5 & 5 \\
\hline \multicolumn{3}{|c|}{ Particle, $\%$ of DM retained on sieve } \\
\hline $19.0 \mathrm{~mm}$ & 14.8 & 19.8 \\
\hline $8.0 \mathrm{~mm}$ & 24.6 & 21.8 \\
\hline $1.18 \mathrm{~mm}$ & 39.0 & 27.4 \\
\hline Pan & 21.6 & 31.0 \\
\hline \multicolumn{3}{|c|}{ Nutrient composition, \% of DM } \\
\hline DM & 52.2 & 52.2 \\
\hline Crude protein & 14.2 & 14.3 \\
\hline NDF & 38.3 & 38.5 \\
\hline ADF & 21.3 & 21.0 \\
\hline Starch & 25.1 & 25.0 \\
\hline RDS & 15.3 & 17.5 \\
\hline peNDF $_{1.18}$ & 23.4 & 25.5 \\
\hline peNDF $_{1.18} / \mathrm{RDS}$ & 1.53 & 1.46 \\
\hline
\end{tabular}

peNDF physically effective neutral detergent fiber, RDS rumen degradable starch, Fps:Cps ratio of forage particle size: concentrate particle size a Premix (per kg) contains: Cu 370 mg, Fe 2200 mg, Zn 1800 mg, Mn 800 mg, I $30 \mathrm{mg}$, Se $30 \mathrm{mg}$, Co $50 \mathrm{mg}$, Vitamin A $200 \mathrm{kIU}$, Vitamin $\mathrm{D}_{3} 4500 \mathrm{IU}$, Vitamin E $6500 \mathrm{IU}$, Vitamin $\mathrm{K}_{3} 45 \mathrm{mg}$, Vitamin $\mathrm{B}_{1} 40 \mathrm{mg}$, Vitamin $\mathrm{B}_{12} 1 \mathrm{mg}$, Nicotinic acid $1,000 \mathrm{mg}$ and Pantothenic acid $700 \mathrm{mg}$

pumped at a rate of $2 \mathrm{~L} / \mathrm{min}$ to the $\mathrm{CH}_{4}$ analyzer and $\mathrm{CO}_{2}$ analyzer with infrared sensors (BAIF-Maihak Analytical Instrument Co., Ltd., China). The gases in the 4 chambers were analyzed sequentially, $5 \mathrm{~min}$ for each chamber in every $20 \mathrm{~min}$.

The daily $\mathrm{CH}_{4}$ emission was calculated as follows:

$$
\begin{aligned}
\mathrm{CH}_{4} \text { emission }(\mathrm{L} / \mathrm{d})= & \Sigma\left[\left(\mathrm{C}_{\mathrm{i}}-\mathrm{C}_{\mathrm{i}-1}\right) \times \mathrm{V}_{\mathrm{c}}+\mathrm{V}_{\mathrm{f}}\right. \\
& \left.\times\left(\mathrm{C}_{\mathrm{i}}-\mathrm{C}_{0}\right)\right] / 1000
\end{aligned}
$$

Where $\left(\mathrm{C}_{\mathrm{i}}-\mathrm{C}_{\mathrm{i}-1}\right)=$ the difference of $\mathrm{CH}_{4}$ concentration $\left(\mathrm{mL} / \mathrm{m}^{3}\right)$ in every $20 \mathrm{~min} ; \mathrm{C}_{0}=$ the initial $\mathrm{CH}_{4}$ concentration of each period; $\mathrm{V}_{\mathrm{c}}=$ the chamber volume $\left(83.9 \mathrm{~m}^{3}\right)$; and $\mathrm{V}_{\mathrm{f}}=$ the gas volume pumped from each chamber over each 20 -min measurement $\left(0.04 \mathrm{~m}^{3}\right)$.
Collection and analysis of ruminal fluid

Samples of ruminal fluid (over $80 \mathrm{~mL}$ ) were collected through the cannula from the ventral rumen sac at threehour sampling intervals on d $20(07: 00,10: 00,13: 00$, 16:00 h), d 21 (08:00, 11:00, 14:00, 17:00 h) and d 22 (09:00, 12:00, 15:00, 18:00 h). For each rumen fluid sample, $\mathrm{pH}$ was measured immediately, and a $40-\mathrm{mL}$ subsample and an 8-mL filtered subsample were stored at $80{ }^{\circ} \mathrm{C}$ for later analyses of bacterial abundances and volatile fatty acid (VFA) concentrations, respectively. The filtered subsample was passed through four layers of gauze.

Ruminal VFA concentrations of each sample was analyzed by gas chromatography (Agilent Technologies 7820A GC system, Santa Clara, USA) using a $30 \mathrm{~m} \times$ $0.25 \mathrm{~mm} \times 0.33 \mu \mathrm{m}$ fused silica column (AE-FFAP; ATECH Technologies Co., Ltd. China) after removing the solid particle and protein in the sample according to Li et al. [26].

The samples taken at 12 sampling times from the individual goats were thawed, and equal aliquots $(1 \mathrm{~mL})$ from each sample were composited into one sample, and then $200 \mu \mathrm{L}$ of the composited sample was extracted total DNA using QIAamp DNA Stool Mini Kit (QIAgen, Valencia, CA) according to the manufacturer's recommendation. The density and purification of the DNA samples were detected by gel electrophoresis and spectrophotometry (NanDrop 2000, Thermo Scientific, Madison, Wisconsin, USA). The $16 \mathrm{~S}$ rDNA primers [27, 28 ] used to identify the methanogen, primary cellulolytic bacteria (B. fibrisolvens, $F$. succinogenes and $R$. flavefaciens) and fumarate-utilizing bacteria (F. succinogenes and S. ruminantium) in the rumen are listed in Table 3. The program and chemicals for quantitative real-time PCR assays were performed on a Bio-Rad iQ5 (Bio-Rad Laboratories, Hercules, CA, USA) according to Zhao et al. [29]. The relative population abundances of the

\begin{tabular}{|c|c|c|}
\hline Target specie & Primer & Primer sequence ( $5^{\prime}$ to $\left.3^{\prime}\right)$ \\
\hline \multirow[t]{2}{*}{ Bacteria $^{a}$} & Forward & CGGCAACGAGCGCAACCC \\
\hline & Reverse & CCATTGTAGCACGTGTGTAGCC \\
\hline \multirow[t]{2}{*}{ Methanogen b } & Forward & GAGGAAGGAGTGGACGACGGTA \\
\hline & Reverse & ACGGGCGGTGTGTGCAAG \\
\hline \multirow[t]{2}{*}{ B. fibrisolvens ${ }^{b}$} & Forward & GAGGAAGTAAAAGTCGTAACAAGGTTTC \\
\hline & Reverse & CAAATTCACAAAGGGTAGGATGATT \\
\hline \multirow[t]{2}{*}{ F. succinogenes ${ }^{a}$} & Forward & GTTCGGAATTACTGGGCGTAAA \\
\hline & Reverse & CGCCTGCCCCTGAACTATC \\
\hline \multirow[t]{2}{*}{ R.flavefaciens ${ }^{a}$} & Forward & CGAACGGAGATAATTTGAGTTACTTAGG \\
\hline & Reverse & CGGTCTCTGTATGTTATGAGGTATTACC \\
\hline \multirow[t]{2}{*}{ S. ruminantium ${ }^{b}$} & Forward & GGCGGGAAGGCAAGTCAGTC \\
\hline & Reverse & ССТСТССТGCACTCAAGAAAGACAG \\
\hline
\end{tabular}

Table 3 PCR primers for real-time PCR assay

${ }^{\mathrm{a} D e n m a n}$ and McSweeney, [27]; ${ }^{\mathrm{b}}$ Khafipour et al. [28] 
specific bacteria were expressed as the percentages to the total bacterial $16 \mathrm{~S}$ rDNA gene.

\section{In situ ruminal degradation}

The in situ degradations of DM of the concentrate and alfalfa hay were performed according to NRC [30] on d 23 to 26 . The concentrate and alfalfa hay were milled through a 2-mm screen. Subsamples of $5.0 \mathrm{~g}$ concentrate or $2.5 \mathrm{~g}$ alfalfa hay (DM basis) were placed in nylon bags $(10 \mathrm{~cm} \times 7 \mathrm{~cm})$ with pore size of $50 \mu \mathrm{m}$. Bags were soaked in $37{ }^{\circ} \mathrm{C}$ water for $10 \mathrm{~min}$ before being inserted into the rumen. Bags with concentrate were taken out in duplicate after $2,4,8,16,24$ and $48 \mathrm{~h}$ of the incubation, while bags with alfalfa hay were incubated in duplicate for $2,4,8,16,24,48$ and $72 \mathrm{~h}$. Bags were washed clean under tap water and then analyzed for DM contents. The degradation parameters and effective ruminal degradability (ERD) were calculated according to the following model [31]:

$$
\begin{aligned}
& \mathrm{Y}_{t}=a+b \times\left(1-\mathrm{e}^{-k t}\right), \\
& \mathrm{ERD}=a+b \times k /(k+k p)
\end{aligned}
$$

In which $\mathrm{Y}_{t}=$ disappearance proportion at time $t$, $a=$ rapidly degradable fraction; $b=$ slowly degradable fraction; $k=$ constant rate of degradation of fraction $b$; $t=$ time of incubation (h); $k p=$ passage rate $(0.04 / \mathrm{h}$ for forage and $0.06 / h$ for concentrate [32]).

\section{Chemical analysis of feedstuff samples}

Samples of the diets and orts were dried at $55{ }^{\circ} \mathrm{C}$ for $72 \mathrm{~h}$ and then ground through a 1-mm screen. Samples were analyzed for the content of DM, ash, crude protein according to AOAC [33], NDF and ADF according to Van Soest et al. [34] with sodium sulfite and heat stable $\alpha$-amylase (Ankom ${ }^{\bullet}$ A200I fiber analyzer, ANKOM technology, Macedon, NY, USA).

Dietary peNDF content was calculated by the following formula [35]: $\mathrm{peNDF}=$ pef $_{1.18} \times \mathrm{NDF}_{1.18}$, in which pef 1.18 represents the percent weight (DM basis) of particles retained above the $1.18-\mathrm{mm}$ sieve of the Penn State Particle Separator [15], and $\mathrm{NDF}_{1.18}$ is the NDF content of particles retained on the 1.18 -mm sieve.

Dietary RDS content was calculated by the following formula [36]: $\mathrm{RDS}=\Sigma P_{i} \times \mathrm{ERD}_{i}$, in which $P_{i}$ represents the proportion of starch content of feed $i$ in the diet, $\mathrm{ERD}_{i}$ represents starch ERD of feed $i$, which included concentrate, alfalfa hay and corn silage, and were measured twice before and after feeding experiment. The starch content of feed and samples of in situ degradation was measured by a commercial Total Starch Assay kit (Megazyme, International Ireland Ltd., Bray, Co. Ireland).

\section{Data analysis}

The data were analyzed using the MIXED procedure of SAS 9.2 (SAS Institute Inc., Cary, NC); Fps:Cps, FA, and their interaction were fixed factors, and experimental period and animal were random factors. When there was an interaction, Tukey's multiple comparison tests were used to assess differences among treatment means.

The dynamics of ruminal $\mathrm{pH}$ after the morning feeding were analyzed as a one-way repeated measures ANOVA using the PROC MIXED program in SAS; Fps:Cps, FA, and their interaction were fixed factors, experimental period and animal were random factors, and sample time was the repeated factor. The dynamics of ruminal $\mathrm{pH}$ after the morning feeding on $\mathrm{d} 21$ were different with the other $2 \mathrm{~d}$, due to sampling stress at feeding time $(08: 00 \mathrm{~h})$ resulting in a much longer eating duration; therefore, the results of ruminal $\mathrm{pH}$ at 08:00, 11:00, 14:00, 17:00 $\mathrm{h}$ on $\mathrm{d} 21$ and 18:00 h (afternoon feeding) on $\mathrm{d} 22$ were not included in this analysis. The dynamics of ruminal $\mathrm{pH}$ after the morning feeding were performed separately for Fps:Cps and FA in figure, as no interaction between them was observed at any time point.

The probability level was set at $P<0.05$ for significance and $0.05 \leq P<0.10$ for trend.

\section{Results \\ Methane production}

On average, the daily dry matter intake (DMI) was $1.08 \mathrm{~kg}$ per goat that over $95 \%$ of the diets offered was consumed. No difference $(P>0.1)$ in DMI was observed among treatments. Fumaric acid supplementation decreased $\mathrm{CH}_{4}$ production $(P<0.05)$ in goats, expressed as $\mathrm{L} / \mathrm{d}$ or as $\mathrm{L} / \mathrm{kg}$ DMI, independently of the dietary Fps:Cps (Table 4). Although the interaction between dietary Fps:Cps and FA was not significantly related to $\mathrm{CH}_{4}$ production, the reduction in $\mathrm{CH}_{4}$ production with FA was greater in the low-Fps:Cps diet (31.72\%) than in the high-Fps:Cps diet (17.9\%).

\section{Ruminal fermentation characteristics}

The effects of dietary Fps:Cps and FA on ruminal fermentation parameters are shown in Table 4. FA supplementation decreased the ruminal total VFA concentration $(P<0.01)$ and raised $\mathrm{pH}(P<0.05)$, independently of the dietary Fps:Cps. Both increasing dietary Fps:Cps and FA supplementation reduced $(P<0.01)$ the ruminal acetate proportion and the ratio of acetate to propionate $(\mathrm{A}: \mathrm{P})$, and increased $(P<0.01)$ propionate proportion. An interaction between dietary Fps:Cps and FA was observed for the A:P $(P<0.05)$, and a tendency was observed for the propionate proportion $(P=0.07)$. FA increased ruminal propionate proportion by $39 \%$ in the low-Fps:Cps diet and by 15\% in the high-Fps:Cps diet, and decreased the A:P by $26 \%$ in the low-Fps:Cps diet 
Table 4 Effects of dietary Fps:Cps and FA supplementation ( 0 or $24 \mathrm{~g} / \mathrm{d}$ ) on $\mathrm{CH}_{4}$ emissions and ruminal fermentation parameters

\begin{tabular}{|c|c|c|c|c|c|c|c|c|}
\hline \multirow{2}{*}{$\begin{array}{l}\text { Items } \\
\text { FA, g/d }\end{array}$} & \multicolumn{2}{|c|}{ Low-Fps:Cps } & \multicolumn{2}{|c|}{ High-Fps:Cps } & \multirow[b]{2}{*}{ SEM } & \multicolumn{3}{|l|}{$P$-value } \\
\hline & 0 & 24 & 0 & 24 & & Fps:Cps & FA & $(F p s: C p s) \times F A$ \\
\hline $\mathrm{CH}_{4}, \mathrm{~L} / \mathrm{d}$ & 23.14 & 15.80 & 22.84 & 18.75 & 1.245 & 0.552 & 0.021 & 0.466 \\
\hline $\mathrm{CH}_{4} / \mathrm{DMl}, \mathrm{L} / \mathrm{kg}$ & 21.03 & 14.54 & 20.94 & 17.95 & 1.044 & 0.365 & 0.020 & 0.341 \\
\hline $\mathrm{pH}$ & 6.38 & 6.52 & 6.40 & 6.51 & 0.027 & 0.887 & 0.020 & 0.817 \\
\hline Total VFA, mmol/L & 89.19 & 85.89 & 87.01 & 80.53 & 1.326 & 0.633 & $<0.001$ & 0.187 \\
\hline \multicolumn{9}{|c|}{ Individual VFA molar proportion, \% } \\
\hline Acetate & 70.24 & 65.50 & 66.93 & 63.50 & 0.526 & 0.009 & $<0.001$ & 0.518 \\
\hline Propionate & 14.80 & 20.58 & 19.07 & 21.98 & 0.437 & 0.001 & $<0.001$ & 0.074 \\
\hline Butyrate & $11.93^{\mathrm{a}}$ & $10.79^{b}$ & $10.82^{b}$ & $11.20^{\mathrm{ab}}$ & 0.170 & 0.303 & 0.259 & 0.026 \\
\hline$A: P$ & $4.89^{\mathrm{a}}$ & $3.62^{\mathrm{b}}$ & $3.74^{b}$ & $3.15^{\mathrm{c}}$ & 0.095 & $<0.001$ & $<0.001$ & 0.048 \\
\hline
\end{tabular}

FA fumaric acid, Fps:Cps ratio of forage particle size: concentrate particle size, $A$ : $P$ Acetate: propionate, SEM pooled standard error of the means ${ }^{a, b}$ Different letters in the same row means significant differences $(P<0.05)$

and by $16 \%$ in the high-Fps:Cps diet. In addition, an (Fps:Cps) $\times$ FA interaction effect also occurred $(P<0.05)$ for butyrate proportion, which was reduced $(P<0.05)$ by FA in the low-Fps:Cps diet but not affected in the highFps:Cps diet.

Ruminal pH dropped after feeding $(P<0.001)$, with a nadir at $4^{\text {th }}$ postprandial hour in all groups, and increased thereafter (Fig. 1). There was no (Fps:Cps) $\times$ FA interaction at any sample time point $(P>0.1)$. The dynamics of ruminal $\mathrm{pH}$ after the morning feeding between low- and high-Fps:Cps diet was consistent $(P>0.1)$, except that the ruminal $\mathrm{pH}$ was higher at the $5^{\text {th }}$ postprandial hour in the low-Fps:Cps diet than in the high-Fps:Cps diet (Fig. 1a). Fumaric acid supplementation attenuated the ruminal $\mathrm{pH}$ drop after feeding, and the attenuation was dependent on time $(P<0.01)$, as the ruminal $\mathrm{pH}$ increased $(P<0.05)$ with FA from the $2^{\text {nd }}$ to the $5^{\text {th }}$ postprandial hours and tended to increase $(P=0.08)$ at the $1^{\text {st }}$ postprandial hour.

\section{Ruminal bacterial population abundances and in situ degradation of DM}

Fumaric acid supplementation reduced the abundance of methanogens $(P<0.05$, Table 5$)$ in the rumen. The abundance of $B$. fibrisolvens was lower in goats fed the lowFps:Cps diet than the high-Fps:Cps diet $(P<0.05)$. No differences in the abundances of $F$. succinogenes, $R$. flavefaciens, or S. ruminantium were observed among treatments.

Neither dietary Fps:Cps nor FA had any impact on ruminal degradation kinetic parameters or on the ERD of the concentrate or alfalfa hay DM in goats $(P>0.1$, Table 6).

\section{Discussion}

Dietary model of Fps:Cps and its effects on methane production and rumen fermentation

In this study, we established a dietary model of Fps:Cps based on the dietary forage: concentrate ratio. Increasing dietary forage: concentrate ratio and decreasing dietary

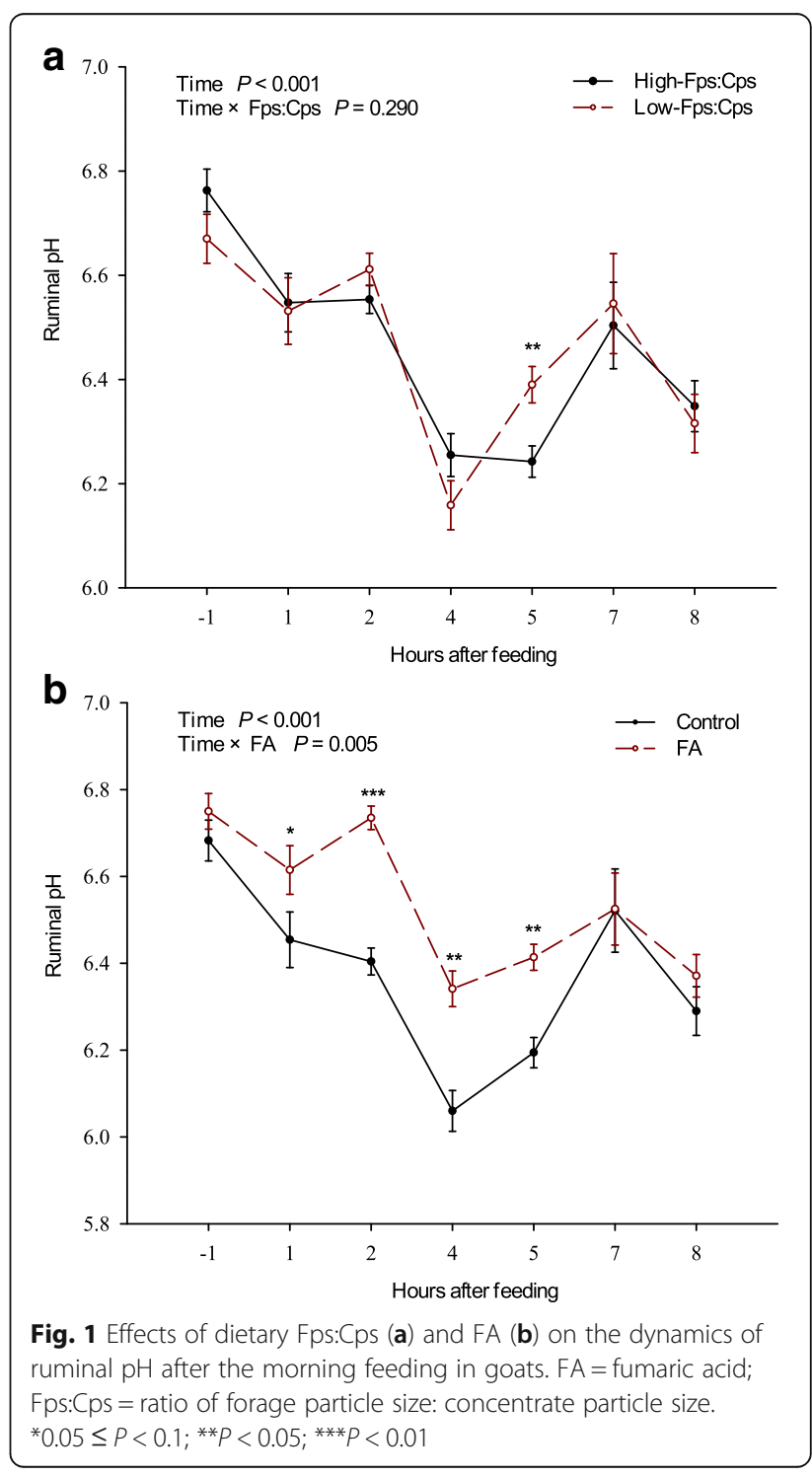


Table 5 Effects of dietary Fps:Cps and FA supplementation (0 or $24 \mathrm{~g} / \mathrm{d}$ ) on the relative abundances of rumen bacteria

\begin{tabular}{|c|c|c|c|c|c|c|c|c|}
\hline \multirow{2}{*}{$\begin{array}{l}\text { Items } \\
\text { FA, g/d }\end{array}$} & \multicolumn{2}{|c|}{ Low-Fps:Cps } & \multicolumn{2}{|c|}{ High-Fps:Cps } & \multirow[b]{2}{*}{ SEM } & \multicolumn{3}{|l|}{$P$-value } \\
\hline & 0 & 24 & 0 & 24 & & Fps:Cps & FA & $(F p s: C p s) \times F A$ \\
\hline \multicolumn{9}{|c|}{ Total bacterial abundance, $\times 10^{-4}$} \\
\hline Methanogens & 15.11 & 12.37 & 15.84 & 12.67 & 0.699 & 0.711 & 0.036 & 0.875 \\
\hline F. succinogenes & 89.26 & 86.72 & 81.61 & 91.17 & 4.493 & 0.861 & 0.703 & 0.511 \\
\hline R. flavefaciens & 2.10 & 2.03 & 1.81 & 2.14 & 0.121 & 0.725 & 0.611 & 0.443 \\
\hline S. ruminantium & 8.21 & 8.72 & 7.79 & 8.36 & 0.261 & 0.467 & 0.312 & 0.965 \\
\hline B. fibrisolvens & 4.07 & 3.87 & 5.36 & 4.84 & 0.233 & 0.014 & 0.408 & 0.711 \\
\hline
\end{tabular}

FA fumaric acid, Fps:Cps ratio of forage particle size: concentrate particle size, SEM pooled standard error of the means

Data are expressed as a fraction of the total bacterial $16 \mathrm{~S}$ rDNA

Fps:Cps represented offering more forage and less concentrate available for ruminal microbes and enzymes, in amount and in surface area, respectively. Adjusting dietary Fps:Cps altered the dietary physical characteristics without changing the dietary chemical composition but also changed the dietary fermentation characteristics in the rumen such that the A:P was lower in goats fed the high-Fps:Cps diet. Consistently, both increasing the forage particle size and decreasing the concentrate particle size shifted ruminal VFA patterns toward lower A:P in previous studies $[15,17,18]$. However, neither the ruminal total VFA concentration nor in situ degradations of the concentrate or alfalfa hay DM were affected by dietary Fps:Cps in this study, indicating that the dietary Fps:Cps manipulated ruminal fermentation pathways mainly by shifting availability of feedstuff surface area $[13,16,19]$ rather than shifting the capacity of ruminal degradability. In contrast, Plaizier et al. [37] found that ground wheat and barley decreased the ruminal degradability of mixed hay DM and NDF in dairy cows with a lower average ruminal $\mathrm{pH}$ of 5.87 . However, the $\mathrm{pH}$ optima for ruminal protozoa, primary cellulolytic bacteria and most secondary bacteria are 6.2 or higher [22].
Furthermore, considering the negative correlation between ruminal degradation and $\mathrm{pH}[38,39]$, the absence of changes in ruminal degradation kinetic parameters or ERD was partly attributed to the similar diurnal fluctuations in rumen $\mathrm{pH}$ between low- and highFps:Cps diets. It is commonly believed that balancing the amount of dietary peNDF and RDS is a key to manipulating ruminal $\mathrm{pH}$ and maintaining proper rumen metabolism [19-21]. The ratios of peNDF to RDS were 1.53 and 1.46 in the low-Fps:Cps diet and the highFps:Cps diet, respectively, higher than the ratio of 1.43 suggested by $\mathrm{Li}$ et al. [26] to lower the risk of subacute ruminal acidosis in dairy goats.

Fermentative acetate production during rumen fermentation is accompanied by hydrogen production, whereas propionate production is accompanied by hydrogen consumption $[12,40]$. However, in the current experiment, increasing dietary Fps:Cps had no effect on $\mathrm{CH}_{4}$ production, although it decreased the ruminal A:P. Based on the pathways of carbohydrate fermentation, the hydrogen available for methanogenesis depends not only on the ruminal VFA profiles but also on the amount of dietary carbohydrate fermented. As illustrated

Table 6 Effects of dietary Fps:Cps and FA supplementation (0 or 24 g/d) on in situ DM degradability

\begin{tabular}{|c|c|c|c|c|c|c|c|c|}
\hline \multirow{2}{*}{$\begin{array}{l}\text { Diets } \\
F A, g / d\end{array}$} & \multicolumn{2}{|c|}{ Low-Fps:Cps } & \multicolumn{2}{|c|}{ High-Fps:Cps } & \multirow[b]{2}{*}{ SEM } & \multicolumn{3}{|l|}{$P$-value } \\
\hline & 0 & 24 & 0 & 24 & & Fps:Cps & FA & Fps:Cps $\times$ FA \\
\hline \multicolumn{9}{|c|}{ Concentrate DM, \% } \\
\hline$a$ & 11.83 & 13.77 & 10.18 & 11.19 & 2.315 & 0.715 & 0.749 & 0.959 \\
\hline$b$ & 91.09 & 85.21 & 84.09 & 84.75 & 2.491 & 0.498 & 0.634 & 0.551 \\
\hline$k_{1} / \mathrm{h}$ & 4.95 & 5.98 & 6.43 & 6.01 & 0.283 & 0.194 & 0.586 & 0.209 \\
\hline ERD & 68.16 & 69.35 & 67.37 & 67.74 & 1.256 & 0.674 & 0.781 & 0.884 \\
\hline \multicolumn{9}{|c|}{ Alfalfa hay DM, \% } \\
\hline$a$ & 16.18 & 15.00 & 18.39 & 15.08 & 1.647 & 0.755 & 0.545 & 0.773 \\
\hline$b$ & 37.95 & 41.19 & 41.06 & 39.04 & 1.164 & 0.850 & 0.808 & 0.310 \\
\hline$k, / h$ & 11.45 & 11.12 & 8.54 & 13.42 & 1.545 & 0.927 & 0.505 & 0.446 \\
\hline ERD & 47.45 & 48.67 & 51.26 & 47.08 & 0.970 & 0.560 & 0.446 & 0.181 \\
\hline
\end{tabular}

FA fumaric acid, Fps:Cps ratio of forage particle size: concentrate particle size, SEM pooled standard error of the means 
by Janssen [12], dissolved hydrogen concentration in the rumen was higher in animals fed readily digestible feed; therefore, hydrogen-suppression with low ruminal A:P in the goats fed high-Fps:Cps diet was compensated by more RDS fermented in the rumen. In addition, adjusting dietary Fps:Cps might affect the methanogenesis by influencing digesta passage, animal chewing and ruminating activities, and ruminal motility [21, 23] besides by influencing ruminal VFA profiles and degradation kinetics; however, these pathways might also cancel each other out in this study. Hironaka et al. [41] observed that reducing the particle size of alfalfa hay had no effect on $\mathrm{CH}_{4}$ emissions in steers, either. Consequently, further studies are required to better understand the relationships among those metabolic pathways on methanogenesis.

\section{Fumaric acid and its relationships with dietary Fps:Cps}

Fumaric acid supplementation altered the ruminal fermentation pathways toward more propionate production and lower $\mathrm{CH}_{4}$ emissions, agreeing with previous studies [5-7]. Theoretically, conversion of all $24 \mathrm{~g}$ FA $(0.21 \mathrm{~mol})$ to propionate could potentially reduce $\mathrm{CH}_{4}$ production by $1.27 \mathrm{~L} / \mathrm{d}$ (FA: hydrogen: $\mathrm{CH}_{4}=4 \mathrm{~mol}: 4 \mathrm{~mol}: 1 \mathrm{~mol}$, $\left.24.5 \mathrm{~L} / \mathrm{mol} \mathrm{CH}_{4}\right)$, which is much lower than the actual reduction (mean of $6.49 \mathrm{~L} / \mathrm{d}$ in the low-Fps:Cps diet and $4.09 \mathrm{~L} / \mathrm{d}$ in the high-Fps:Cps diet) in this study. Yang et al. [5] and van Zijderveld et al. [42] also observed that the actual reduction in $\mathrm{CH}_{4}$ production with $\mathrm{FA}$ was greater than the potential reduction, which indicated that the $\mathrm{CH}_{4}$-suppressing effects of FA were not only attributable to its function as an alternative electronacceptor to methanogenesis. Although the abundances of fumarate-utilizing bacteria (F. succinogenes and $S$. ruminantium) were not affected by FA in this study, FA likely stimulated fumarate-utilizing bacteria and thus increased the ruminal activity of the succinatepropionate metabolic pathway $[5,43]$, which stimulated other substrates (such as starch and fiber) in feed to be fermented as propionate. Moreover, the contributions to propionate increase with FA by the stimulation of fumarate-utilizing bacteria may be larger than the conversion of FA itself. The increase in ruminal propionate production with FA would have a starvation effect on methanogens, such as hydrogenotrophic archaea, reducing their abundance, which agrees with our results and those of a previous study [5].

In the current study, FA supplementation to the lowFps:Cps diet showed greater responses in $\mathrm{CH}_{4}$ mitigation and propionate increase. Considering that the hydrogen affinity of FA is lower than that of methanogenesis [44-46], high dissolved hydrogen concentrations in the rumen would accelerate the conversion of FA to propionate according to the thermodynamic principle [11]. Dissolved hydrogen concentrations in the rumen was higher in animals fed readily digestible feed [12, 47]. Therefore, the metabolism of FA was slower in the animals fed lowFps:Cps diet than fed high-Fps:Cps diet, and the duration of the positive stimulation of FA on fumarate-utilizing bacteria became longer, resulting in greater responses in $\mathrm{CH}_{4}$ mitigation and propionate increase. This suggests that the responses to FA depend on the rumen's capacity to metabolize FA, rather than the direct interactions between FA and dietary nutrients. This theory also explained why FA supplementation in high-forage diets showed greater responses than that in low-forage diets $[5,10]$. The abundances of fumarate-utilizing bacteria (F. succinogenes and $S$. ruminantium) in the rumen between low- and highFps:Cps diets were not different; however, they can also influence the rumen's capacity to metabolize FA. Therefore, more studies are needed to fully understand the relationship between fumarate-utilizing bacteria abundances and ruminal responses to FA.

To our knowledge, little information is available regarding the effects of FA on in situ degradation of feedstuff. In the present study, the in situ degradability of DM in the concentrate and alfalfa hay were not affected by FA supplementation, but interestingly, the ruminal total VFA concentration was reduced. Considering that ruminal $\mathrm{pH}$ is negatively related to total VFA concentration [48], an increase in ruminal $\mathrm{pH}$ with FA would be expected, consistent with that of previous studies $[9,49]$. An alternative explanation to the higher ruminal $\mathrm{pH}$ might be that FA stimulated fumarateutilizing bacteria to uptake lactic acid $[9,50]$. Inconsistently, Remling et al. [51] reported that adding FA (300 or $600 \mathrm{~g}$ ) to diets for cattle decreased the rumen $\mathrm{pH}$, and Vyas et al. [8] and McGinn et al. [52] reported no changes in ruminal $\mathrm{pH}$ with FA supplementation. Thus, the effects of FA supplementation on ruminal $\mathrm{pH}$ need to be further confirmed. In addition, the effect of FA on increasing ruminal $\mathrm{pH}$ was dependent on time after feeding, as FA increased the $\mathrm{pH}$ during the first $5 \mathrm{~h}$ after feeding but had no effect thereafter, indicating the duration of FA metabolization in the rumen.

\section{Conclusion}

Dietary Fps:Cps is an alternative dietary model to dietary forage-to-concentrate ratio for studying diet-dependent effects, and it could manipulate ruminal fermentation patterns without the confounding effect of varying dietary nutrient composition. Increases in propionate with FA were attributed to its conversion to propionate and its positive stimulation of fumarate-utilizing bacteria, resulting in the actual $\mathrm{CH}_{4}$-depressing effects of FA being greater than the anticipated effects. The responses to FA supplementation likely depend on the rumen's capacity to metabolize FA, with the low-Fps:Cps diet showing greater responses. 


\section{Abbreviations}

A:P: Acetate to propionate ratio; ADF: Acid detergent fiber; DM: Dry matter; ERD: Effective ruminal degradability; FA: Fumaric acid; Fps:Cps: Ratio of forage particle size: concentrate particle size; NDF: Neutral detergent fiber; peNDF: Physically effective neutral detergent fiber; RDS: Rumen degradable starch; VFA: Volatile fatty acids

\section{Acknowledgments}

This research was financially supported by the National Key Research and Development Program of China (2017YFD0500500) and Key Research and Development Program of Shaanxi Province (2017ZDXM-NY-086). The authors thank Alltech Inc. for technic supports to operate the environmentally controlled chambers.

\section{Funding}

This research was supported by the National Key Research and Development Program of China (2017YFD0500500) and Key Research and Development Program of Shaanxi Province (2017ZDXM-NY-086).

\section{Availability of data and materials}

All the datasets were presented in the main manuscript and available to readers.

\section{Authors' contributions}

Conceived and designed the experiments: ZJL, NNL and JHY. Performed the experiments: ZJL, NNL and CJJ. Analyzed the data: NNL, FL and CJC. Contributed to the writing of the manuscript: ZJL, NNL and YCC. All authors read and approved the final manuscript.

\section{Ethics approval and consent to participate}

Not applicable.

\section{Consent for publication}

Not applicable.

\section{Competing interests}

The authors declare that they have no competing interests.

\section{Author details}

'College of Animal Science and Technology, Northwest A\&F University, Yangling, Shaanxi 712100, China. ${ }^{2}$ College of Pastoral Agricultural Science and Technology, Lanzhou University, Lanzhou 730020, China.

\section{Received: 21 June 2017 Accepted: 12 January 2018}

Published online: 09 February 2018

\section{References}

1. Johnson KA, Johnson DE. Methane emissions from cattle. J Anim Sci. 1995; 73:2483-92.

2. Ripple WJ, Smith P, Haberl H, Montzka SA, McAlpine C, Boucher DH. Ruminants, climate change and climate policy. Nat Clim Chang. 2014;4:2-5.

3. Shabat SKB, Sasson G, Doron-Faigenboim A, Durman T, Yaacoby S, Berg Miller ME, et al. Specific microbiome-dependent mechanisms underlie the energy harvest efficiency of ruminants. ISME J. 2016; https://doi.org/10.1038/ ismej.2016.62

4. Li F, Guan LL. Metatranscriptomic profiling reveals linkages between the active rumen microbiome and feed efficiency in beef cattle. Appl Environ Microbiol. 2017;83:e00061-17.

5. Yang CJ, Mao SY, Long LM, Zhu WY. Effect of disodium fumarate on microbial abundance, ruminal fermentation and methane emission in goats under different forage : concentrate ratios. Animal. 2012;6:1788-94.

6. Li XZ, Long RJ, Yan CG, Choi SH, Jin GL, Song MK. Rumen microbial responses in fermentation characteristics and production of CLA and methane to linoleic acid in associated with malate or fumarate. Anim Feed Sci Technol. 2010;155:132-9.

7. Patra A, Park T, Kim M, Yu Z. Rumen methanogens and mitigation of methane emission by anti-methanogenic compounds and substances. J Anim Sci Biotechnol. 2017;8:13.

8. Vyas D, Beauchemin KA, Koenig KM. Using organic acids to control subacute ruminal acidosis and fermentation in feedlot cattle fed a highgrain diet. J Anim Sci. 2015;93:3950.
9. Nardi RD, Marchesini G, Plaizier JC, Li S, Khafipour E, Ricci R, et al. Use of dicarboxylic acids and polyphenols to attenuate reticular pH drop and acute phase response in dairy heifers fed a high grain diet. BMC Vet Res. 2014;10:277.

10. García-Martínez R, Ranilla MJ, Tejido ML, Carro MD. Effects of disodium fumarate on in vitro rumen microbial growth, methane production and fermentation of diets differing in their forage: concentrate ratio. $\mathrm{Br} J$ Nutr. 2005:94:71-7.

11. Ungerfeld EM, Kohn RA, Wallace RJ, Newbold CJ. A meta-analysis of fumarate effects on methane production in ruminal batch cultures. J Anim Sci. 2007;85:2556-63.

12. Janssen PH. Influence of hydrogen on rumen methane formation and fermentation balances through microbial growth kinetics and fermentation thermodynamics. Anim Feed Sci Technol. 2010;160:1-22.

13. Galyean ML, Wagner DG, Owens FN. Dry matter and starch disappearance of corn and sorghum as influenced by particle size and processing. J Dairy Sci. 1981;64:1804-12

14. Theurer CB. Grain processing effects on starch utilization by ruminants. J Anim Sci. 1986:63:1649-62.

15. Kononoff PJ, Heinrichs AJ, Lehman HA. The effect of corn silage particle size on eating behavior, chewing activities, and rumen fermentation in lactating dairy cows. J Dairy Sci. 2003;86:3343-53.

16. Tafaj M, Zebeli Q, Baes C, Steingass H, Drochner W. A meta-analysis examining effects of particle size of total mixed rations on intake, rumen digestion and milk production in high-yielding dairy cows in early lactation. Anim Feed Sci Technol. 2007;138:137-61.

17. Krause KM, Combs DK, Beauchemin KA. Effects of forage particle size and grain fermentability in midlactation cows. II. Ruminal pH and chewing activity. J Dairy Sci. 2002;85:1947-57.

18. Mohammed R, Kennelly JJ, Kramer JKG, Beauchemin KA, Stanton CS, Murphy J. Effect of grain type and processing method on rumen fermentation and milk rumenic acid production. Animal. 2010;4:1425-44.

19. Nasrollahi SM, Khorvash M, Ghorbani GR, Teimouri-Yansari A, Zali A, Zebeli Q. Grain source and marginal changes in forage particle size modulate digestive processes and nutrient intake of dairy cows. Animal. 2012;6:1237-45.

20. Zebeli Q, Mansmann D, Steingass H, Ametaj BN. Balancing diets for physically effective fibre and ruminally degradable starch: a key to lower the risk of sub-acute rumen acidosis and improve productivity of dairy cattle. Livest Sci. 2010;127:1-10

21. Zebeli Q, Aschenbach JR, Tafaj M, Boguhn J, Ametaj BN, Drochner W. Invited review: role of physically effective fiber and estimation of dietary fiber adequacy in high-producing dairy cattle. J Dairy Sci. 2012;95:1041-56.

22. Reece WO. Dukes' physiology of domestic animals. 12th ed. Ithaca: Comstock Pub. Associates; 2004.

23. Knapp JR, Laur GL, Vadas PA, Weiss WP, Tricarico JM. Invited review: enteric methane in dairy cattle production: quantifying the opportunities and impact of reducing emissions. J Dairy Sci. 2014;97:3231-61.

24. Ministry of Agriculture of China. Feeding standard of meat-producing sheep and goats (NY/Y816-2004). Being, China: China Agricultural Press; 2004.

25. Li ZJ, Ren H, Liu SM, Cai CJ, Han JT, Li F, et al. Dynamics of methanogenesis, ruminal fermentation, and alfalfa degradation during adaptation to monensin supplementation in goats. J. Dairy Sci. 2018;101:1048-59.

26. Li F, Yang XJ, Cao YC, Li SX, Yao JH, Li ZJ, et al. Effects of dietary effective fiber to rumen degradable starch ratios on the risk of sub-acute ruminal acidosis and rumen content fatty acids composition in dairy goat. Anim Feed Sci Technol. 2014;189:54-62.

27. Denman SE, McSweeney CS. Development of a real-time PCR assay for monitoring anaerobic fungal and cellulolytic bacterial populations within the rumen. FEMS Microbiol Ecol. 2006:58:572-82.

28. Khafipour E, Li S, Plaizier JC, Krause DO. Rumen microbiome composition determined using two nutritional models of subacute ruminal acidosis. Appl Environ Microbiol. 2009;75:7115-24.

29. Zhao XH, Liu CJ, Liu Y, Li CY, Yao JH. Effects of replacing dietary starch with neutral detergent-soluble fibre on ruminal fermentation, microbial synthesis and populations of ruminal cellulolytic bacteria using the rumen simulation technique (RUSITEC). J Anim Physiol Anim Nutr. 2013;97:1161-9.

30. National Research Council. Nutrient requirements of dairy cattle. 7th ed. Washington, D.C: National Academic Press; 2001.

31. Ørskov ER, McDonald I. The estimation of protein degradability in the rumen from incubation measurements weighted according to rate of passage. J Agric Sci. 1979;92:499-503. 
32. Offner A, Bach A, Sauvant D. Quantitative review of in situ starch degradation in the rumen. Anim Feed Sci Technol. 2003;106:81-93.

33. AOAC. Official methods of analysis. 18th ed. Gaithersburg, MD: Association of Official Analytical Chemists; 2005.

34. Van Soest PJ, Robertson JB, Lewis BA. Methods for dietary fiber, neutral detergent fiber, and nonstarch polysaccharides in relation to animal nutrition. J Dairy Sci. 1991;74:3583-97.

35. Mertens DR. Creating a system for meeting the fiber requirements of dairy cows. J Dairy Sci. 1997;80:1463-81.

36. Zebeli Q, Dijkstra J, Tafaj M, Steingass H, Ametaj BN, Drochner W. Modeling the adequacy of dietary fiber in dairy cows based on the responses of ruminal $\mathrm{pH}$ and milk fat production to composition of the diet. J Dairy Sci. 2008;91:2046-66.

37. Plaizier JC, Keunen JE, Walton J-P, Duffield TF, McBride BW. Effect of subacute ruminal acidosis on in situ digestion of mixed hay in lactating dairy cows. Can J Anim Sci. 2001;81:421-3.

38. Erdman RA. Dietary buffering requirements of the lactating dairy cow: a review. J Dairy Sci. 1988;71:3246-66.

39. Dijkstra J, Ellis JL, Kebreab E, Strathe AB, López S, France J, et al. Ruminal pH regulation and nutritional consequences of low pH. Anim Feed Sci Technol. 2012;172:22-33.

40. Hegarty RS. Mechanisms for competitively reducing ruminal methanogenesis. Aust J Agric Res. 1999;50:1299-306.

41. Hironaka R, Mathison GW, Kerrigan BK, Vlach I. The effect of pelleting of alfalfa hay on methane production and digestibility by steers. Sci Total Environ. 1996:180:221-7.

42. van Zijderveld SM, Dijkstra J, Perdok HB, Newbold JR, Gerrits WJJ. Dietary inclusion of diallyl disulfide, yucca powder, calcium fumarate, an extruded linseed product, or medium-chain fatty acids does not affect methane production in lactating dairy cows. J Dairy Sci. 2011;94:3094-104.

43. Zhou YW, McSweeney CS, Wang JK, Liu JX. Effects of disodium fumarate on ruminal fermentation and microbial communities in sheep fed on highforage diets. Animal. 2012;6:815-23.

44. Martin SA, Park C-M. Effect of extracellular hydrogen on organic acid utilization by the ruminal bacterium Selenomonas ruminantium. Curr Microbiol. 1996;32:327-31.

45. Asanuma $\mathrm{N}$, Iwamoto $\mathrm{M}$, Hino $\mathrm{T}$. Effect of the addition of fumarate on methane production by ruminal microorganisms in vitro. J Dairy Sci. 1999; 82:780-7.

46. Ellis JL, Dijkstra J, Kebreab E, Bannink A, Odongo NE, McBRIDE BW, et al. Aspects of rumen microbiology central to mechanistic modelling of methane production in cattle. J Agric Sci. 2008;146:213-33.

47. Wang M, Wang R, Xie TY, Janssen PH, Sun XZ, Beauchemin KA, et al. Shifts in rumen fermentation and microbiota are associated with dissolved ruminal hydrogen concentrations in lactating dairy cows fed different types of carbohydrates. J Nutr. 2016;146:1714-21.

48. Packer EL, Clayton EH, Cusack PMV. Rumen fermentation and liveweight gain in beef cattle treated with monensin and grazing lush forage. Aust Vet J. 2011;89:338-45.

49. Molano G, Knight TW, Clark H. Fumaric acid supplements have no effect on methane emissions per unit of feed intake in wether lambs. Aust J Exp Agric. 2008;48:165.

50. Martin SA. Manipulation of ruminal fermentation with organic acids: a review. J Anim Sci. 1998;76:3123-32.

51. Remling N, Riede S, Lebzien P, Meyer U, Höltershinken M, Kersten S, et al. Effects of fumaric acid on rumen fermentation, milk composition and metabolic parameters in lactating cows. J Anim Physiol Anim Nutr. 2013;98:968-81.

52. McGinn SM, Beauchemin KA, Coates T, Colombatto D. Methane emissions from beef cattle: effects of monensin, sunflower oil, enzymes, yeast, and fumaric acid. J Anim Sci. 2004;82:3346-56.

\section{Submit your next manuscript to BioMed Central and we will help you at every step:}

- We accept pre-submission inquiries

- Our selector tool helps you to find the most relevant journal

- We provide round the clock customer support

- Convenient online submission

- Thorough peer review

- Inclusion in PubMed and all major indexing services

- Maximum visibility for your research

Submit your manuscript at www.biomedcentral.com/submit

) Biomed Central 